\title{
Iodine Status of School Age Children 6-12 Years in Umuahia South LGA of Abia State, Nigeria
}

\author{
A.D. Oguizu ${ }^{* 1}$, J.O. Nwagwu ${ }^{2}$ \\ ${ }^{1}$ Senior Lecturer, Department of Human Nutrition and Dietetics, Michael Okpara University of Agriculture, \\ Umudike, P.M.B. 7267, Umuahia, Abia State, Nigeria \\ Email: ada.ejekwu@gmail.com \\ ${ }^{2}$ Graduate Student, Department of Human Nutrition and Dietetics, Michael Okpara University of Agriculture, \\ Umudike, P.M.B. 7267, Umuahia, Abia State, Nigeria
}

\begin{abstract}
Background: Iodine deficiency disorders have continued to be a significant health problem in some Nigerian communities despite universal salt iodization.

Objective: This study was designed to assess the iodine status of school age children (6-12 years) in Umuahia South LGA of Abia State, Nigeria.

Methods: A total of 414 school children were studied. Urine samples were obtained from 84 school children, 30 males and 54 females. The background and socio-economic information, food habit and dietary intake of the respondents were determined using validated questionnaires. Urinary iodine concentration analysis, using Sandell-Kolthoff reaction was used to determine the iodine status of the children. Chi-square was used to determine the relationship between urinary iodine status of the children and the socio-economic characteristics of their parents.

Results: More than half $(58.7 \%)$ of the children were females while $40.5 \%$ were males. About a quarter of the children $(40.1 \%)$ were $9-10$ years, $23.4 \%$ were $11-12$ years while $36.5 \%$ were $6-8$ years. Most of the respondents $(72.2 \%)$ were aware of iodized salt; $14.3 \%$ heard about iodized salt from friends, $41.8 \%$ heard from the media while $13 \%$ heard about iodized salt from the market. Majority of the respondents (94.4\%) claimed they consume iodized salt while $4.9 \%$ said they use salts that were measured in cups which was not iodized salt. The study revealed that $54.3 \%$ of the school children had optimal iodine status while $35.7 \%$ had mild iodine deficiency which was higher in males $(46.7 \%)$ than in females $(29.6 \%)$. About $5.6 \%$ of the respondents had grade 1 goiter. There was a significant association $(\mathrm{p}<0.05)$ between urinary iodine status of the school children and educational status of their fathers', mothers', parents' occupation and income level of fathers.

Conclusion: Nutrition education should be aimed at mothers, caregivers, and school children to promote consumption of iodine rich foods.
\end{abstract}

Keywords - School Age Children; Iodine Status; Abia State; Nigeria.

\section{Introduction}

Micronutrient deficiencies continue to impose health, economic and social burden worldwide. Due to lack of resources, limited education and resulting poor nutritional practices, many non-industrialized countries, such as Nigeria, struggle to maintain adequate nutritional status for the entire population. Iodine is a trace element, which is essential to human and animal health in small doses. Iodine forms an important constituent of the thyroid hormones, thyroxin (T4) and triiodothyronine (T3). These hormones play a fundamental biological role controlling growth and development (Hetzel and Maberly, 2006). If the amount of utilizable iodine reaching the thyroid gland is deficient or if the thyroid gland is not functioning properly, the hormone production will be reduced resulting in a group of conditions in man, collectively referred to as Iodine deficiency disorders (IDD) (Fernando et al., 2007).

Iodine deficiency disorders (IDD) is a global public health problem. It is one of the oldest and most insidious of human health problems. Iodine deficiency not only causes goiters, but may also result in irreversible brain damage and retard psychomotor development in children. Iodine deficiency is the most common cause of preventable mental retardation; it also affects a child's learning ability (Zimmermann et al., 2006). School age is the active growing phase of childhood; it represents a dynamic period of physical growth as well as mental development of a child.

Children are particularly vulnerable to under nutrition, as priority in nutrition intervention is often to prevent malnutrition during fetal development and the first years of life. School age children, 6-12 years old, form a useful study group for assessing iodine deficiency because of their physiological vulnerability to disease, their accessibility through school (Joshi et al., 2006). Most research among school age children in Abia State has focused on prevalence of severe acute malnutrition among school-age children. Therefore, this study was aimed to assess the iodine status of school age children (6-12 years) in Umuahia South LGA of Abia State. 


\section{Materials and Methods}

\subsection{Study Design}

A cross sectional study design and experimental design was used for the study.

\subsection{Area of Study}

The study was carried out in Umuahia South LGA, Abia State. Umuahia South is one out of the 17 local government areas in Abia State. The climate is tropical and humid all year round. Annual rainfall ranges from $2000 \mathrm{~mm}$ to $2500 \mathrm{~mm}$, temperature ranges within $22^{\circ} \mathrm{C}$ and $38^{\circ} \mathrm{C}$. The LGA is largely inhabited by the Igbo people (one of the three major ethnic groups in Nigeria). Their economy depends mainly on agriculture and commerce.

\subsection{Population of the Study}

The population of this study focused on school-age children (6-12 years) in Umuahia South LGA.

\section{Sampling and Sampling Techniques}

\subsection{Sample Size Determination}

$\mathrm{N}=\frac{\mathrm{Z}^{2} \mathrm{p}(100-\mathrm{P})}{\mathrm{x}^{2}}$ (Winn et al., 2006)

Where $\mathrm{N}=$ sample size

$\mathrm{Z}=$ confidence interval at $95 \%$ degree of probability which is $1.96 \%$ approximately $2 \%$

$\mathrm{P}=$ estimated percentage of the subject used in the survey and its assumed findings.

$100-\mathrm{P}=$ number of non-estimated percentage and unissued findings

$\mathrm{X}^{2}=$ width of confidence interval at $5 \%$ level of probability

$\mathrm{P}=$ Prevalence of Hypothyroidism (55.6\%)

$\mathrm{N}=\frac{1.96^{2}}{5^{2}} 55.6(100-55.6)$

$\mathrm{N}=\frac{\mathrm{a.9416}}{25} 55.6(44.4)$

$\mathrm{N}=\frac{2.8416(2446.4)}{25}$

$\mathrm{N}=\frac{9398.0902}{25}$

$\mathrm{N}=375.9 \approx 376$

Calculating drop out.

$\frac{10}{100}$ (376)

$0.1(376)=37.6$

Therefore, $\mathrm{N}=37.6+376=413.6$

$\mathrm{N}=414$.

For biochemical analysis, $20 \%$ of the total population was used.

$20 \%$ of $414=\mathrm{N}=\frac{20}{100}(414)$

$0.2(414)=83$

\subsection{Sampling Procedure}

A multistage sampling technique was used in this study. The first stage involved the random selection of the schools. A list of all the primary schools in Umuahia South L.G.A was gotten from the local government. There were a total of 89 primary schools (48 public schools and 41 private schools) in Umuahia South L.G.A. A simple random sampling technique by way of balloting without replacement was used in the selection of 9 schools used for this. The schools selected comprised of 4 public schools and 5 private schools. The class register was used to select of the school children; distribution of pupils by age and sex were obtained from class registers. List of pupil aged $6-$ 12 years in all the classes of the schools was compiled and a total number of 46 children were randomly selected from each school by way of balloting without replacement. This was repeated in all the 9 schools. A total of 414 school age children participated in the survey.

\subsection{Informed Consent and Ethical Clearance}

A written consent to interview and examine each child was obtained from their parents/ caregivers via letters sent through the children. Ethical clearance was obtained from Federal Medical Center, Umuahia Abia State.

\subsection{Data Collection}

A well-structured validated questionnaire was used to collect information from the parents on the socio-economic status, personal characteristics and dietary intake of the children. Information such as: family size, date of birth, occupation of parents' educational level, and monthly income of parents. Data were also collected by interviewing the children with the help of their class teachers. Plastic containers with labeled sticker $(10 \mathrm{ml})$ were used to collect the urine. Data on urinary iodine variables were collected and completed on the questionnaire.

\subsection{Urinary Iodine Assessment}

A trained laboratory personnel obtained $5 \mathrm{mls}$ of urine in $20 \%$ of the subjects. The urine samples were stored in a trace element free urine collecting tubes. $250 \mu \mathrm{l}$ of each urine sample was made up to a final volume of $259 \mu 1$ with deionized water in test tubes (WHO et al., 2001). Then $1 \mathrm{ml}$ of $0.1 \mathrm{~mol}$ ammonium persulfate was added to each of the test tubes, they were heated for 60 minutes at $1000^{\circ} \mathrm{C}$. The test tubes were allowed to cool at room temperature. After which $2.5 \mathrm{ml}$ of arsenious acid solution was added, and allowed to stand for 15 minutes. $300 \mu \mathrm{l}$ of ceric ammonium persulfate solution was added to each test tube by stirring at 15-30 seconds interval, and then they were allowed to stand at room temperature. Its absorbance was read at

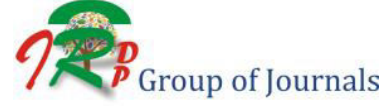


$420 \mathrm{~nm}$ exactly 30 minutes after addition of ceric ammonium persulfate. Iodine deficiency was defined as urinary iodine excretion below 100 $\mu \mathrm{g} / \mathrm{l}$ (WHO et al., 2007). A colorimetric method was used.

\subsection{Iodine Status}

Severe deficiency $(<20 \mu \mathrm{g} / \mathrm{l})$

Moderate deficiency $(20-49 \mu \mathrm{g} / \mathrm{l})$

Mild deficiency $(50-99 \mu \mathrm{g} / \mathrm{l})$

Optimal (100-199 $\mu \mathrm{g} / \mathrm{l})$

More than adequate $(200-299 \mu \mathrm{g} / \mathrm{l})$

Excessive iodine intake $(>300 \mu \mathrm{g} / \mathrm{l})$

\subsection{Neck Inspection and Palpation}

The subjects were asked to stand in front of the examiner, who carefully looked at the neck for any sign of visible thyroid enlargement. The subjects were then asked to look up to fully extend the neck; this pushes the thyroid forward and makes any enlargement more obvious. Finally, the examiner palpates the thyroid by gently sliding her thumb along the side of the trachea (wind-pipe) between the cricoid cartilage and the top of the sternum. Both sides of the trachea are checked. The size and consistency of the thyroid gland are carefully noted. If necessary, the subject was asked to swallow when being examined - the thyroid moves up on swallowing. The size of each lobe of the thyroid is compared to the size of the tip (terminal phalanx) of the thumb of the subject being examined (WHO, UNICEF and ICCIDD, 2001).

Goitre is graded according to the classification presented below.

\subsection{Simplified Classification of Goitre by Palpation}

Grade 0 - No palpable or visible goitre.

Grade 1 - A goitre that is palpable but not visible when the neck is in the normal position (i.e., the thyroid is not visibly enlarged).

Grade 2 - A swelling in the neck that is clearly visible when the neck is in a normal position and is consistent with an enlarged thyroid when the neck is palpated.

\section{Data Analysis}

Data generated from this study were coded and analysed using statistical software package (SPSS) version 24.0. Descriptive statistics; mean, standard deviations, frequencies and percentages were used. Iodine status was classified using standard procedures. Chi-square was used to test the significance of association between the socioeconomic characteristics and urinary iodine status.

\section{Results}

Table 1 shows the characteristics of the respondents. More than half $(58.7 \%)$ of the students were females while $41.3 \%$ were males. About a quarter of the children were between the ages of $9-10$ years $(40.1 \%)$ while $36.5 \%$ were aged between 6-8 years. Only $23.4 \%$ were between the ages of 11-12 years. Majority of the respondents were Igbo $(96.6 \%)$ and Christians (99.5\%). One third of the children $(30.2 \%)$ were in basic 4 , about $20.5 \%$ were in basic 3 while few $(5.3 \%)$ were in basic 1 .

Table 1: Characteristics of the Respondents

\begin{tabular}{|c|c|c|}
\hline Variables & Frequency (F) & Percentage (\%) \\
\hline \multicolumn{3}{|l|}{ Gender } \\
\hline Male & 171 & 41.3 \\
\hline Female & 243 & 58.7 \\
\hline Total & 414 & 100 \\
\hline \multicolumn{3}{|l|}{ Age (years) } \\
\hline 6-8 years & 151 & 36.5 \\
\hline 9-10 years & 166 & 40.1 \\
\hline $11-12$ years & 97 & 23.4 \\
\hline Total & 414 & 100 \\
\hline \multicolumn{3}{|l|}{ Ethnic group } \\
\hline Igbo & 400 & 96.6 \\
\hline Yoruba & 3 & 0.7 \\
\hline Hausa & 2 & 0.5 \\
\hline Others & 9 & 2.2 \\
\hline Total & 414 & 100 \\
\hline \multicolumn{3}{|l|}{ Religion } \\
\hline Christianity & 412 & 99.5 \\
\hline Islam & 2 & 0.5 \\
\hline Total & 414 & 100 \\
\hline \multicolumn{3}{|l|}{$\begin{array}{l}\text { Present class in } \\
\text { school }\end{array}$} \\
\hline Basic 1 & 22 & 5.3 \\
\hline Basic 2 & 54 & 13.0 \\
\hline Basic 3 & 85 & 20.5 \\
\hline Basic 4 & 125 & 30.2 \\
\hline Basic 5 & 66 & 15.9 \\
\hline Basic 6 & 62 & 15.0 \\
\hline Total & 414 & 100 \\
\hline
\end{tabular}

Result from table 2 revealed that $44.4 \%$ of fathers and $27.3 \%$ of mothers were civil servants. About $32.6 \%$ of fathers and $45.7 \%$ of mothers were traders. Very few of the fathers $(5.8 \%)$ and $13.5 \%$ of the mothers were unemployed. A quarter of the fathers $(49.8 \%)$ and mothers $(40.1 \%)$ had secondary education as their highest level of education. Meanwhile, $12.8 \%$ of the fathers and $25.4 \%$ of the mothers earned less than 18,000 , while $30.7 \%$ of the fathers and $13.8 \%$ of the mothers earned above $\$ 60,000$. 
Table 2: Information on Respondents' parents

\begin{tabular}{|c|c|c|c|c|}
\hline Variables & \multicolumn{2}{|c|}{ Fathers } & \multicolumn{2}{|c|}{ Mothers } \\
\hline & $\mathbf{F}$ & $\%$ & $\mathbf{F}$ & $\%$ \\
\hline \multicolumn{5}{|l|}{ Occupation } \\
\hline $\begin{array}{l}\text { Civil } \\
\text { servant }\end{array}$ & 184 & 44.4 & 113 & 27.3 \\
\hline Farmer & 71 & 17.1 & 56 & 13.5 \\
\hline Trader & 135 & 32.6 & 189 & 45.7 \\
\hline $\begin{array}{l}\text { Not } \\
\text { employed }\end{array}$ & 24 & 5.8 & 56 & 13.5 \\
\hline Total & 414 & 100 & 414 & 100 \\
\hline \multicolumn{5}{|l|}{ Education } \\
\hline $\begin{array}{l}\text { No formal } \\
\text { education }\end{array}$ & 23 & 5.6 & 43 & 10.4 \\
\hline Primary & 18 & 4.3 & 47 & 11.4 \\
\hline Secondary & 206 & 49.8 & 166 & 40.1 \\
\hline Tertiary & 167 & 40.3 & 158 & 38.2 \\
\hline Total & 414 & 100 & 414 & 100 \\
\hline \multicolumn{5}{|l|}{ Income } \\
\hline $\begin{array}{l}\text { Less than } \\
118,000\end{array}$ & 53 & 12.8 & 105 & 25.4 \\
\hline $\begin{array}{l}19,000- \\
29,000\end{array}$ & 51 & 12.3 & 81 & 19.6 \\
\hline $\begin{array}{l}\text { N 30,000 - } \\
\text { 39,000 }\end{array}$ & 53 & 12.8 & 71 & 17.1 \\
\hline $\begin{array}{l}40,000- \\
\text { 49,000 }\end{array}$ & 67 & 16.2 & 42 & 10.1 \\
\hline $\begin{array}{l}\text { 50,000- } \\
\text { N 59,000 }\end{array}$ & 63 & 15.2 & 58 & 40.0 \\
\hline $\begin{array}{l}\text { Above } \\
60,000\end{array}$ & 127 & 30.7 & 57 & 13.8 \\
\hline Total & 414 & 100 & 414 & 100 \\
\hline
\end{tabular}

Table 3 shows the dietary habits of the respondents. Majority of the respondents $(84.5 \%)$ ate 3 times daily. Most of the respondents $(72.2 \%)$ were aware of ionized salts while $27.8 \%$ were not aware of ionized salt; their major source of awareness was from Media (41.8\%) and from friends $(14.3 \%)$. The type of salt used in cooking as identified by majority of the respondents $(94.4 \%)$ are salts from small packs with iodine while few of the respondents $(4.9 \%)$ used salts measured and sold in cups. More than half of the respondents $(62.6 \%)$ could identify iodized salt from its labeling.

Table 3: Food habits and awareness level of respondents

\begin{tabular}{|l|c|c|}
\hline Variables & F & \% \\
\hline $\begin{array}{l}\text { Number of times you eat in a } \\
\text { day }\end{array}$ & & \\
\hline Once & 8 & 1.9 \\
\hline 2 times & 56 & 13.5 \\
\hline 3 times & 350 & 84.5 \\
\hline Total & $\mathbf{4 1 4}$ & $\mathbf{1 0 0}$ \\
\hline Awareness of iodized salt & & \\
\hline Yes & 299 & 72.2 \\
\hline No & 115 & 27.8 \\
\hline Total & $\mathbf{4 1 4}$ & $\mathbf{1 0 0}$ \\
\hline
\end{tabular}

\begin{tabular}{|l|c|r|}
\hline Source of awareness & & \\
\hline Media (TV and Radio) & 173 & 41.8 \\
\hline Friends & 59 & 14.3 \\
\hline Relatives & 13 & 3.1 \\
\hline From the market & 54 & 13.0 \\
\hline Total & $\mathbf{4 1 4}$ & $\mathbf{1 0 0}$ \\
\hline Type of salt used at home & 20 & 4.9 \\
\hline $\begin{array}{l}\text { From the ones being measured } \\
\text { and sold in cups }\end{array}$ & 391 & 94.4 \\
\hline $\begin{array}{l}\text { Salts from small packs with } \\
\text { iodine }\end{array}$ & 3 & 0.7 \\
\hline Don't know & $\mathbf{4 1 4}$ & $\mathbf{1 0 0}$ \\
\hline Total & & \\
\hline
\end{tabular}

Table 4 shows the frequency of consumption of iodine rich foods by the children. Result revealed that fish $(71.7 \%)$, milk $(72 \%)$, meat $(72 \%)$, crayfish $(72.5 \%)$, salt $(71.7 \%)$ and rice $(79 \%)$ were consumed by most of the respondents' daily. Only a few consumed oysters $(8.9 \%)$, and green beans $(13.8 \%)$, daily. On weekly basis, a higher percentage of the school children $(53.1 \%)$ consumed yoghurt, $39.6 \%$ took banana while $37.2 \%$ consumed egg weekly.

Table 4: Food frequency consumption of iodine rich foods

\begin{tabular}{|l|c|c|c|c|c|c|c|c|c|c|}
\hline \multirow{2}{*}{$\begin{array}{l}\text { Sources } \\
\text { of food }\end{array}$} & \multicolumn{2}{|c|}{ Daily } & \multicolumn{2}{|c|}{ Weekly } & \multicolumn{2}{c|}{$\begin{array}{c}\text { Mont } \\
\text { hly }\end{array}$} & \multicolumn{2}{|c|}{$\begin{array}{c}\text { Neve } \\
\text { r }\end{array}$} & \multicolumn{2}{|c|}{} \\
\cline { 2 - 11 } & F & $\%$ & F & $\%$ & F & $\%$ & F & $\%$ & F & $\%$ \\
\hline Milk & 298 & 72.0 & 114 & 27.5 & 2 & 0.5 & - & - & 414 & 100 \\
\hline Meat & 298 & 72.0 & 100 & 24.2 & 12 & 2.9 & 4 & 1.0 & 414 & 100 \\
\hline Egg & 248 & 59.9 & 154 & 37.2 & 12 & 2.9 & - & - & 414 & 100 \\
\hline Fish & 297 & 71.7 & 107 & 25.8 & 6 & 1.4 & 4 & 1.0 & 414 & 100 \\
\hline Crayfish & 300 & 72.5 & 73 & 17.6 & 33 & 8.0 & 8 & 1.9 & 414 & 100 \\
\hline Oyster & 37 & 8.9 & 104 & 25.1 & 251 & 60.4 & 22 & 5.3 & 414 & 100 \\
\hline Crabs & 94 & 22.7 & 111 & 26.8 & 206 & 49.8 & 3 & 0.7 & 414 & 100 \\
\hline Periwinkle & 134 & 32.4 & 130 & 31.4 & 142 & 34.3 & 8 & 1.9 & 414 & 100 \\
\hline Rice & 327 & 79.0 & 77 & 18.6 & 6 & 1.4 & 4 & 1.0 & 414 & 100 \\
\hline Maize & 222 & 53.6 & 128 & 30.9 & 63 & 15.2 & 1 & 0.2 & 414 & 100 \\
\hline Wheat & 134 & 32.4 & 139 & 33.6 & 113 & 27.3 & 28 & 6.8 & 414 & 100 \\
\hline Salt (iodized) & 367 & 88.6 & 35 & 8.5 & 11 & 2.7 & 1 & 0.2 & 414 & 100 \\
\hline Banana & 221 & 53.4 & 164 & 39.6 & 26 & 6.3 & 3 & 0.7 & 414 & 100 \\
\hline Yoghurt & 71 & 17.1 & 220 & 53.1 & 119 & 28.7 & 4 & 1.0 & 414 & 100 \\
\hline Green beans & 57 & 13.8 & 95 & 22.9 & 229 & 55.3 & 33 & 8.0 & 414 & 100 \\
\hline
\end{tabular}

Table 5 shows the urinary iodine status of the school children. About $54.3 \%$ of the children had 100-199 $\mu \mathrm{g} / \mathrm{l}$ iodine in their urine which denotes optimal iodine status. However, $35.7 \%$ of the children had $50-99 \mu \mathrm{g} / \mathrm{l}$ iodine in 
their urine which denotes mild iodine deficiency. Males $(46.7 \%)$ had more mild deficiency than females (29.6\%).

Table 5: Iodine status of the children

\begin{tabular}{|c|c|c|c|c|c|c|c|c|}
\hline \multirow[b]{2}{*}{ Variable } & \multicolumn{2}{|c|}{ Male } & \multicolumn{2}{|c|}{$\begin{array}{c}\text { Femal } \\
\text { e }\end{array}$} & \multicolumn{2}{|c|}{ Total } & \multirow{2}{*}{\begin{tabular}{|c|} 
Male \\
Mean \pm \\
SD
\end{tabular}} & \multirow{2}{*}{$\begin{array}{c}\begin{array}{c}\text { Femal } \\
\text { e }\end{array} \\
\text { Mean } \pm \\
\text { SD }\end{array}$} \\
\hline & $\mathbf{F}$ & $\%$ & $\mathbf{F}$ & $\%$ & $\mathbf{F}$ & $\%$ & & \\
\hline $\begin{array}{l}\text { Severe } \\
\text { defic iency }(<20 \\
\mu \mathrm{g} / \mathrm{l})\end{array}$ & - & - & - & - & - & - & - & - \\
\hline $\begin{array}{l}\text { Moderate } \\
\text { defic iency }(20- \\
49 \mu \mathrm{g} / \mathrm{l})\end{array}$ & - & - & - & - & - & - & - & - \\
\hline $\begin{array}{l}\text { Mild deficiency } \\
(50-99 \mu \mathrm{g} / \mathrm{l})\end{array}$ & 14 & 46.7 & 16 & 29.6 & 30 & 35.7 & $\begin{array}{l}94.71 \\
\pm 4.50\end{array}$ & $\begin{array}{l}94.06 \\
\pm 4.60\end{array}$ \\
\hline $\begin{array}{l}\text { Optimal (100- } \\
199 \mu \mathrm{g} / \mathrm{L})\end{array}$ & 16 & 53.3 & 38 & 70.4 & 54 & 54.3 & $\begin{array}{l}106.56 \\
\pm 5.29\end{array}$ & $\begin{array}{l}107.94 \\
\pm 5.35\end{array}$ \\
\hline $\begin{array}{l}\text { More than } \\
\text { adequate }(200- \\
299 \mu \mathrm{g} / \mathrm{l})\end{array}$ & - & - & - & - & - & - & - & - \\
\hline $\begin{array}{l}\text { Excessive } \\
\text { iodine intake } \\
(>300 \mu \mathrm{g} / \mathrm{l})\end{array}$ & - & - & - & - & - & - & - & - \\
\hline Total & 30 & 100 & 54 & 100 & 84 & 100 & $\begin{array}{c}101.03 \\
\pm 7.73 \\
\end{array}$ & $\begin{array}{c}103.83 \\
\pm 8.18 \\
\end{array}$ \\
\hline
\end{tabular}

Table 6 shows the prevalence of goiter through neck inspection and palpation. Results revealed that $5.6 \%$ of the respondents had goiter, while $95.9 \%$ did not show any palpable sign of goiter. More females $(6.6 \%)$ than males $(4.1 \%)$ had palpable goiter.

Table 6: Prevalence of goiter through neck inspection and palpation

\begin{tabular}{|l|c|c|c|c|c|c|}
\hline Category & \multicolumn{2}{|c|}{ Male } & \multicolumn{2}{c|}{ Female } & \multicolumn{2}{c|}{ Total } \\
\hline & F & \% & F & \% & F & $\%$ \\
\hline $\begin{array}{l}\text { Grade 0 } \\
\text { (Normal) }\end{array}$ & 164 & 95.9 & 227 & 93.4 & 391 & 94.4 \\
\hline $\begin{array}{l}\text { Grade 1 } \\
\text { (Palpable) }\end{array}$ & 7 & 4.1 & 16 & 6.6 & 23 & 5.6 \\
\hline $\begin{array}{l}\text { Grade 2 } \\
\text { (Palpated) }\end{array}$ & - & - & - & - & - & - \\
\hline Total & $\mathbf{1 7 1}$ & $\mathbf{1 0 0 . 0}$ & $\mathbf{2 4 3}$ & $\mathbf{1 0 0 . 0}$ & $\mathbf{4 1 4}$ & $\mathbf{1 0 0 . 0}$ \\
\hline
\end{tabular}

Table 7 shows the relationship between urinary iodine status of children and socio-economic characteristics of their parents. Educational status of the fathers was found to have a week negative significant relationship with the urinary iodine status of the children $(p=-0.038)$. The occupation $(\mathrm{p}=0.017)$ and income level $(\mathrm{p}=0.029)$ of the fathers was found to have a strong positive relationship with the urinary iodine status of the children. Result also showed a significant relationship $(p=0.013)$ between mother's educational status and the urinary iodine status of the children.
Table 7: Relationship between iodine status of children and socio-economic characteristics of parents

\begin{tabular}{|c|c|c|c|c|c|c|}
\hline \multicolumn{2}{|c|}{ 'Variable } & \multicolumn{3}{|c|}{ Urinary iodine status } & \multirow[b]{2}{*}{\begin{tabular}{|c}
$\mathbf{X}^{2}-$ \\
value \\
$\mathrm{S}$
\end{tabular}} & \multirow[b]{2}{*}{$\begin{array}{c}\mathbf{P} \\
\text { val } \\
\text { ue }\end{array}$} \\
\hline & & $\begin{array}{c}\text { Mild } \\
\text { deficiency }\end{array}$ & $\begin{array}{r}\text { Optimal } \\
\text { deficiency }\end{array}$ & Total & & \\
\hline & & F (\%) & F (\%) & F (\%) & & \\
\hline \multirow[t]{5}{*}{$\begin{array}{l}\text { Educatio } \\
\text { nal status } \\
\text { of father }\end{array}$} & \begin{tabular}{|l|} 
No \\
formal \\
education
\end{tabular} & $0(0.0 \%)$ & $2(100 \%)$ & $2(100 \%)$ & \multirow[t]{5}{*}{3.591} & \multirow{5}{*}{0.038} \\
\hline & Primary & $0(0.0 \%)$ & $4(100 \%)$ & $4(100 \%)$ & & \\
\hline & $\begin{array}{l}\text { Secondar } \\
\text { y }\end{array}$ & $18(38.3 \%)$ & $29(61.7 \%)$ & $47(100 \%)$ & & \\
\hline & Tertiary & $12(38.7 \%)$ & $19(61.3 \%)$ & $31(100 \%)$ & & \\
\hline & Total & $30(35.7 \%)$ & $54(64.3)$ & $84(100 \%)$ & & \\
\hline \multirow{5}{*}{$\begin{array}{l}\text { Occupati } \\
\text { on of } \\
\text { father }\end{array}$} & $\begin{array}{l}\text { Civil } \\
\text { servant }\end{array}$ & $16(32.7 \%)$ & $33(67.3 \%)$ & $49(100 \%)$ & \multirow{5}{*}{6.051} & \multirow{5}{*}{0.017} \\
\hline & Farmer & $4(50 \%)$ & $4(50 \%)$ & $8(100 \%)$ & & \\
\hline & Trader & $8(57.1 \%)$ & $6(42.9 \%)$ & $14(100 \%)$ & & \\
\hline & \begin{tabular}{|l|} 
Not \\
employed
\end{tabular} & $2(15.4 \%)$ & $11(84.6 \%)$ & $13(100 \%)$ & & \\
\hline & Total & $30(35.7 \%)$ & $54(64.3)$ & $84(100 \%)$ & & \\
\hline \multirow[t]{8}{*}{$\begin{array}{l}\text { Income } \\
\text { of father }\end{array}$} & $\begin{array}{l}\text { Less than } \\
118,000\end{array}$ & $9(33.3 \%)$ & $18(66.7 \%)$ & $27(100 \%)$ & \multirow{8}{*}{3.689} & \multirow{7}{*}{90.029} \\
\hline & \begin{tabular}{|l|} 
\\
$19,000-$ \\
$\mathrm{N} 29,000$ \\
\end{tabular} & $7(50 \%)$ & $7(50 \%)$ & $14(100 \%)$ & & \\
\hline & \begin{tabular}{|l|}
30,000 \\
-1 \\
39,000 \\
\end{tabular} & $3(25 \%)$ & $9(75 \%)$ & $12(100 \%)$ & & \\
\hline & \begin{tabular}{|l|} 
\\
$40,000-$ \\
49,000
\end{tabular} & $8(42.1 \%)$ & $11(57.9 \%)$ & $19(100 \%)$ & & \\
\hline & \begin{tabular}{|l|} 
\\
$50,000-$ \\
$N 59,000$
\end{tabular} & $1(14.3 \%)$ & $6(85.7 \%)$ & $7(100 \%)$ & & \\
\hline & $\begin{array}{l}\text { Above } \mathrm{N} \\
60,000\end{array}$ & $2(40 \%)$ & $3(60 \%)$ & $5(100 \%)$ & & \\
\hline & Total & & $54(64.3)$ & $84(100 \%)$ & & \\
\hline & & $30(35.7 \%)$ & & & & \\
\hline \multirow[t]{5}{*}{$\begin{array}{l}\text { Educatio } \\
\text { nal status } \\
\text { of mothe }\end{array}$} & $\begin{array}{l}\text { No } \\
\text { formal } \\
\text { education }\end{array}$ & $1(100 \%)$ & $0(0.0 \%)$ & $1(100 \%)$ & \multirow[t]{5}{*}{1.996} & \multirow[t]{5}{*}{50.013} \\
\hline & Primary & $6(37.5 \%)$ & $10(62.5 \%)$ & $16(100 \%)$ & & \\
\hline & $\begin{array}{l}\text { Secondar } \\
\mathrm{y}\end{array}$ & $11(32.4 \%)$ & $23(67.6 \%)$ & $34(100 \%)$ & & \\
\hline & Tertiary & $12(36.4 \%)$ & $21(63.6 \%)$ & $33(100 \%)$ & & \\
\hline & Total & $30(35.7 \%)$ & $54(64.3)$ & $84(100 \%)$ & & \\
\hline \multirow{5}{*}{$\begin{array}{l}\text { Occupati } \\
\text { on of } \\
\text { mother }\end{array}$} & \begin{tabular}{|l} 
Civil \\
servant
\end{tabular} & $15(45.5 \%)$ & $18(54.5 \%)$ & $33(100 \%)$ & \multirow{5}{*}{2.734} & \multirow{5}{*}{0.434} \\
\hline & Farmer & $1(33.3 \%)$ & $2(66.7 \%)$ & $3(100 \%)$ & & \\
\hline & Trader & $13(31 \%)$ & $29(69 \%)$ & $42(100 \%)$ & & \\
\hline & \begin{tabular}{|l|} 
Not \\
employed
\end{tabular} & $1(16.7 \%)$ & $5(83.3 \%)$ & $6(100 \%)$ & & \\
\hline & Total & $30(35.7 \%)$ & $54(64.3)$ & $84(100 \%)$ & & \\
\hline
\end{tabular}






\section{Discussions}

Characteristics of the respondents revealed that more than half of the students were females and about a quarter of them males. This finding is not consistent with that of National Demographic and Health Survey (NDHS, 2013) where it was reported that there were more males than females. School age children, 6-12 years old, form a useful study group for assessing iodine deficiency because of their physiological vulnerability to disease, their accessibility through school and as a representation of iodine deficiency in the community (Joshi et al, 2006; Biswas et al, 2006). Majority of the respondents were Igbo and Christians. This is so because the area where this study was conducted is dominated by the Igbo community who are Christians. A quarter of fathers and less than one third of mothers were civil servants. This finding is consistent with that of Oguizu and Alozie. (2018). A quarter of the fathers and mothers had secondary education as their highest level of education. This is in contrast with the report of Oguizu and Alozie. (2018) which revealed that majority of fathers $(64.6 \%)$ and mothers $(63.1 \%)$ in their study area had tertiary educations as their highest level of education. From the study, fathers $(5.6 \%)$ and mothers $(10.4 \%)$ who had no formal education is higher than that reported of Oguizu and Alozie (2018) where, fathers (1.5\%) and mothers $(2.3 \%)$ had no formal education. The slight difference may be because the sample size used for this study is quite higher than that of Oguizu and Alozie (2018). Majority of the respondents ate 3 times in a day. This is highly commendable and should be encouraged; consumption of breakfast can boost a child's diet by meeting the daily nutrient intake requirement, promoting healthful food choices and it is also associated with better academic performances. Majority of the respondents were aware of ionized salts while $27.8 \%$ were not aware of ionized salt. Oguizu and Alozie. (2018) noted that all the respondents $(100 \%)$ in their study claimed to have heard of iodized salt. The type of salt used in cooking as identified by majority of the respondents is iodized salts. This finding justifies the claim by NDHS. (2013) that almost all households (97\%) in Nigeria use iodized salts. This result also supports NAFDAC Nigeria claim that the government had greatly promoted salt iodization using public campaigns and Nigeria was certified for sustained universal salt iodization compliance (95-98\%) as at year 2005 .

The food frequency consumption revealed fish, milk, meat, crayfish, salt and rice were consumed daily by majority of the respondents. Children are particularly vulnerable to under nutrition. To develop to their optimal potential, it is vital that children are provided with nutritionally adequate diets. The urinary iodine status of the school children revealed that half of the children had optimal iodine status while about one third of them had mild iodine deficiency. This is slightly in consonance with the research conducted by Oguizu and Alozie. (2018) which revealed that $50.8 \%$ of the children studied had optimal iodine status, while about $24.6 \%$ had mild iodine deficiency. Neck inspection and palpation revealed that $5.6 \%$ of the respondents had goiter; females $6.6 \%$, males $4.1 \%$. The goiter rate observed among the primary school children agrees with the WHO declaration of 2004, that iodine deficiency was still a public health problem in most countries. A total goiter rate (TGR) of $>5 \%$ can be taken as a public health problem in a population (WHO/UNICEF/ICCIDD, 2001). This study recorded no severe iodine deficiency and this is a welcome development in terms of public health and could attest that lots of families have massively embraced consumption of iodized salt. Educational status, occupation and income level of the fathers had a positive association $(\mathrm{p}<0.05)$ with the urinary iodine status of the children. Mother's educational status also had a positive association $(\mathrm{p}<0.05)$ with the urinary iodine status of the children. This suggests that living standard has direct relationship with iodine nutritional status. A higher total goiter rate in low income respondents could be because of food insecurity; including less meat, vegetable and iodized salt consumption and iodized salt.

\section{Conclusion}

Most of the children studied were within the ages of 9 and 10 years. Majority of the fathers were civil servants. Majority of the mothers were traders. Most of the respondents agreed to have heard about iodized salt and a greater percentage of them got the information from the media. The iodine status of the children showed that none of the children studied were severely deficient and none had excessive iodine status. However, half of them had optimal levels of urinary iodine with one third of them being mildly deficient. Prevalence of goiter among school children in the study area has been identified, which is a severe public health problem. The problem was found to be 
more prevalent among males than females. The result of this investigation demonstrates that despite normal median urinary iodine observed, cases of insufficient iodine intake still exist. More males than the females had mild urinary iodine deficiency. There is a significant relationship between educational status of father and mother, occupation and income level of fathers and urinary iodine status of the school children.

\section{Reference}

[1] Biswas, A.B., Chakraborty, I., Das, D.K. and Roy, R.N. Assessment of iodine deficiency disorders in Purulia district, West Bengal, India. Journal Tropical Pediatric, 2006. 52: 288-92.

[2] Fernando, S., Balasuriya, K.B., Herath, S.and Katugampola, M.A. Endemic goiter in Sri Lanka. In. C.B.Dissanayake, L.Gunatilaka, (Eds); some aspects of the environment of Sri Lanka. Colombo: Sri Lanka Association for the Advancement of Science, 2007. 46-64

[3] Hetzel, H.S. and Maberly, G.F. Trace elements in human and animal nutrition. Academic Press International council London, 2006. 139197.

[4] Joshi, A.B., Banjara, M.R., Bhatta, L.R., Rikimaru, T. and Jimba, M Assessment of IDD problem by estimation of urinary iodine among school children. Nutrition Medical Clinical Journal, 2006. 89: 111114.
[5] Nigeria demographic and health survey. National Population Commission Federal Republic of Nigeria Abuja, Nigeria. ICF International Rockville, Maryland, USA. Nigeria, 2013. 18-32.

[6] Oguizu A.D. and Alozie P.C. Iodine status and academic performance of school age children (6-12 years) in Umuahia North local government area, Abia State Nigeria. International Journal of Food Science and Nutrition, 2018. 106-110.

[7] Pedersen, I.B, Laurberg, P., Knudsen, N., et al. An increased incidence of overt hypothyroidism after iodine fortification of salt in Denmark: a prospective population study. Journal Clinical Endocrinological Metabolism, 2007. 92:3122-27.

[8] WHO/UNICEF/ICCIDD. Assessment of Iodine Deficiency Disorders and Monitoring their Elimination: A Guide for Program Managers, 3rd ed. World Health Organization, Geneva, Switzerland, 2007.

[9] Winn T, Naing L, Rusli BN. Practical issues in calculating the sample size for prevalence studies. Arch. Orofacial Sci., 2006. 1:914.

[10] World Health Organization/International Council for the Control of the Iodine Deficiency Disorders/United Nations Children's Fund (WHO/ICCIDD/UNICEF). Assessment of the iodine deficiency disorders and monitoring their elimination. $3^{\text {rd }}$ Edition Geneva: World Health Organization, 2007.

[11] Zimmermann, M.B., Connolly, K., Bozo, M., Bridson, J., Rohner, F., and Grimci, L. Iodine supplementation improves cognition in iodine-deficient school children in Albania: a randomized, controlled, double-blind study. American Journal Clinical Nutrition, 2006. 83:108-114. 